\title{
New life of postindustrial factories in Bialystok - chosen aspects
}

\author{
Andrzej Tokajuk \\ https://orcid.org/0000-0002-7532-6414 \\ a.tokajuk@pb.edu.pl
}

Faculty of Architecture, Bialystok University of Technology

\section{Ewa Tokajuk}

https://orcid.org/0000-0001-5799-7305

e.tokajuk@pb.edu.pl

Faculty of Engineering Management, Bialystok University of Technology

\begin{abstract}
The revitalization is one of the most essential processes associated with transformations of urban structures in the $20^{\text {th }}$ and $21^{\text {st }}$ centuries. Revitalization actions, carried out in Polish cities at the beginning of the $21^{\text {st }}$ century, concern mainly postindustrial areas and buildings. The most known revitalization operations in Poland have been carried out in Lodz and Poznan. The authors of the article will present analyses concerning revitalization problems of some old factories in Bialystok - former significant centre of the textile industry in Poland in the end of $19^{\text {th }}$ and first half of the $20^{\text {th }}$ century. The authors will present significant architectural, spatial and economical effects of such transformations.

The research was carried out in the frame of scientific project No. S/WA/2/2016 at the Bialystok University of Technology, Faculty of Architecture and financed from science research sources by Polish Ministry of Science and Higher Education.
\end{abstract}

Keywords: postindustrial factory, revitalization, architecture

\section{Introduction}

Revitalization is regarded by many specialists as main topic of urban planning and architecture in developed countries, it is also taking the essential place in the New Athens Charter (Lisboa 2003). It constitutes the sum of actions on destroyed areas which were taken in the social, spatial and econoomical aspects leading to transformation of cities. This process consists of the implementation "... of package of programs and projects appearing to eliminate problems in different fields of municipal economics and to create conditions for new investments and the modernization of the city space." [Gorgon, Sikorska-Starzewska, 2007] A general purpose of the revitalization is the harmonious and many-sided development of cities through adaptations to new needs what guarantees the improvement of living conditions in the city, integration of historical and contemporary forms. In the opinion of scientics it should be "... planning activity directed to the area of the entire city and successively to chosen its areas, above all historical, from $19^{\text {th }}$ century and also development comes from the $20^{\text {th }}$ century." [Sumien, Furman, Ufnalewska, Was, 1989] The restoration is a complex process, it concerns architecture and the urban planning, technical infrastructure, economic, administrative, sustainalbe and social issues. The scope of revitalization, containing in the state law programmes of revitalization, touches the aspect of public and social changes, i.e. of the revival of degraded and destroyed areas which is supposed to lead into the improvement the standsrds of life of local community living on the given area. [Podrecznik rewitalizacji, 2003] According the European dimension the revitalization is being defined as the process of solving the problem of the urban area in the social, economic and spatial sphere. [Gorgon, Sikorska-Starzewska, 2007] 
In the context of the spatial aspects the revitalization most often concerns the following areas of the building development:

- housing - they are characterized by a structural and technical diversity;

- city centre - usually areas located in the centre of the specific urban area;

- landscape areas - sports, recreational, ancient graveyards, etc.;

- postindustrial - previously important for the economic development of the city, at present not-used appropriately;

- shipyard industry areas with its infrastructure ;

- postmilitary areas;

- associated with the railway infrastructure ;

n urban wasteland - areas which are developed temporarily or not used at all. [Lorens, 2009]

Posrindustrial areas requiring the revitalization are very special and they requeir spacial attention. Scale of such problems in Polish cities, caused by the socioeconomic transformation from 1990, is very big and at the same time diversified. The greatest needs in this respect are appearing in industrialized regions, so as the Silesian, Mazovian, Lodz Provinces. In more poorly industrialized provinces the problem of the revitalization is smaller. In Bialystok - the capital of the Podlaskie Province, called at one time because of the developed light industry "Manchester of the north", needs of the revitalization of postindustrial development are relatively big and it is important problem for the further development of the city. One should notice that in Poland the process of the revitalization which is taken hold from the year 2000 is en element "of national strategy of the regional development" as the object of the strategic planning. Since then they started to adapt Polish law to procedures of the European regional policy. [Jadach-Sepiolo, 2010]

\section{Conditions of the industrialization of Bialystok in the second half of $19^{\text {th }}$ and the first half of the $20^{\text {th }}$ centuries}

Numerous, favourable conditions caused, that Białystok region became the important centre of the textile industry in the $19^{\text {th }}$ century. The main causes were:

- economic factors (existence of the local cheap labour, appearance the significant number of workers in cities after granting freehold to peasants in 1864);

- political factors (implementing the custom border in 1831 between the Russion Empire and the Congress Kingdom of Poland established in 1815 at the Congress of Vienna - it caused, that buissnessmen had moved their factories from the Kingdom to Białystok region being in borders of Russia);

- geographical conditions (existence of many rivers, from which water was being used in the technological process, local resource base in the form of sheep's wool);

- structure of the railway connections (starting of Warsaw-Petersburg railways in 1862, enabled the access the component materials as well as the possibility to export textile goods to Russia, China, America and Japan);

- crisis of the textile industry in the Lodz district (caused by introducing customs duties by Russion government). [Wasiluk, 1998]

Only after 1831, after implementing the custom border many manufactures started into existence in the neighbourhood of Bialystok. In the city of Białystok the majority of factories were not located, because of the high land taxes, lack of possibilities of acquiring the cheap labour. Only in the next period of the development of the city, in years 1843-1914 it changed, and Białystok became industrial - commercially - financial centre. [Dobronski, 1998] (Table 1). Białystok became the dominating centre of the textile industry. Next period in the city development were years 1918-1939. In Bialystok still a textile industry dominated, however the city lost during the world war many stores, factory buildings and the majority of machines. In the interwar period they rebuilt smaller companies, employing fewer than 50 workers, located within the city chaotically, by chance. 
Table 1. Dynamics of growth the textile industry in Białystok in years 1857-1937.

\begin{tabular}{|c|c|c|}
\hline Year & Number of factories & Number of Wolkers \\
\hline 1857 & 10 & 453 \\
\hline 1879 & 47 & 1568 \\
\hline 1890 & 81 & 2608 \\
\hline 1907 & 232 & 5089 \\
\hline 1910 & 126 & 4013 \\
\hline 1922 & 113 & 4520 \\
\hline 1937 & 68 & 6930 \\
\hline
\end{tabular}

Source: own study on the base [Werwicki, 1957]

How it appears from Table 1, the rate of development in terms of the number of units and the number of the employed in them was great. Białystok became the important industrial centre in the region. A dominating role of Białystok was in the years 70 . of the $19^{\text {th }}$ century. In 1910 Białystok had about $63 \%$ open textile units in the region. Four years later already functioned $84.7 \%$ (in Białystok - 177 companies, with the whole in the district - 209). There were factories of the cloth and wool products -12 , weaving milles -87 , spinning milles - 40, companies manufacturing of cotton - 7. [Werwicki, 1957] The most well-known Białystok factories from the $19^{\text {th }}$ and $20^{\text {th }}$ century were: Ch.N. Aronson and Stein Factory of silk from 1889, S. Zilberblatt and Chany Marejn weaving milles of wool products company (15 factories) from years 1876 - 1884, E. Becker Factory of silk products from 1883, J.Flakier Factory of the cloth from 1890, H.Commichau Factory of wool products and the factory of cloth from 1849 and 1880, C.Nowik Factory of weaving mill of wool products from 1868, L. Rozental Factory weaving mill of wool products from 1870, J.Trylling Factory of the cloth and the weaving mill from 1863, the Hasbach family Factory from 1865, G. Herbsta Factory of cloth from 1877. [Werwicki, 1957] According to the list from 1907 in Białystok 232 textile companies operated. However in 1914 the value of their production only equalled $8 \%$ of textile production of Lodz, so Białystok industrial district as "younger brother of Łódź" was not so strong. [Dobronski, 1998] Sources allow to establish locations of 51 Białystok companies.

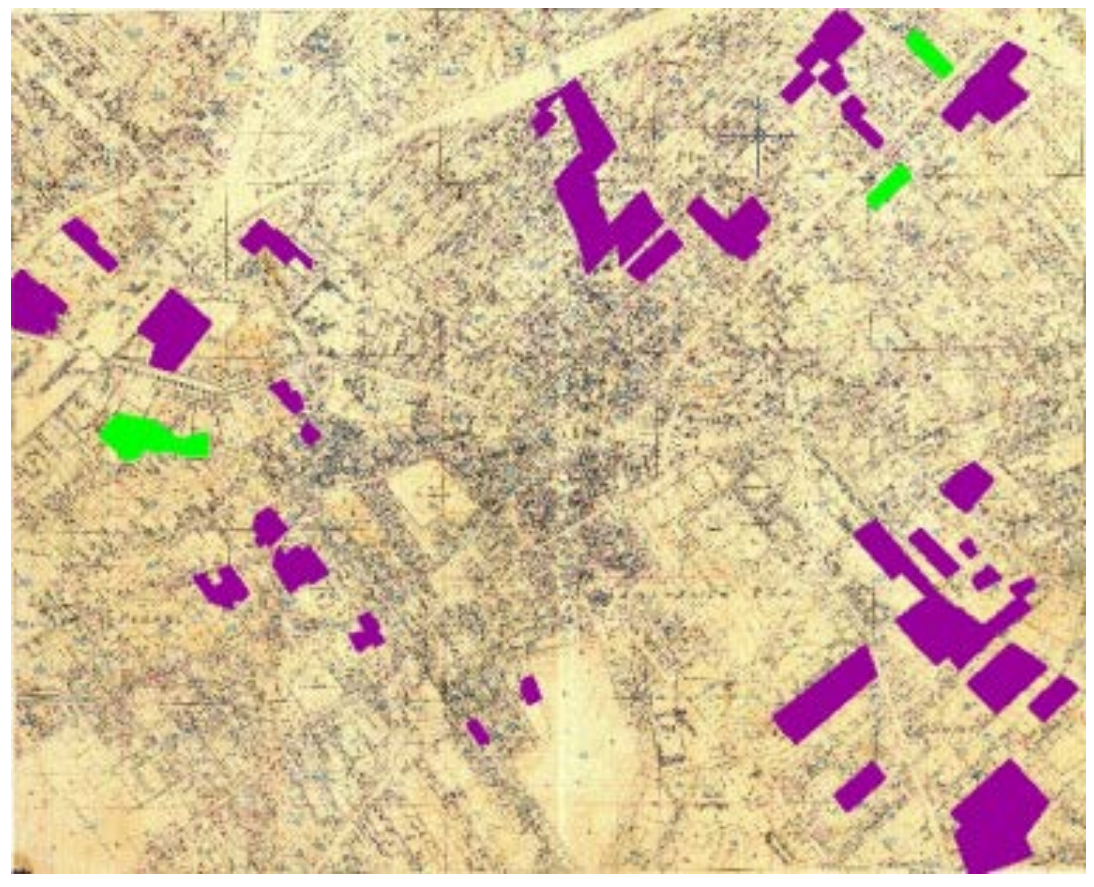

Fig. 1. Location of the biggest prewar industrial factories in Białystok - state for 1937. Source: own study 
Unfortunately, many factory buildings in Białystok didn't survive up till today. A few objects permanently took root in the landscape of Białystok, creating the element of history and the tradition of the city. The speciality of the Białystok textile industry were companies of incomplete production cycle, low-capital, set to quick profits. This architecture was simple and modest. Facades of buildings were left nonplastered, they were being adorned with only cornices, usually of brick often in two colours, arranged decoratively.

Table 2. The biggest textile factories of Białystok - state from 1910

\begin{tabular}{|c|c|c|}
\hline Company & The year of establishing & Number of workers \\
\hline Aronson I. & 1888 & 54 \\
\hline Braunek i Foss & 1876 & 198 \\
\hline Commichau H. & 1845 & 150 \\
\hline Commichau and sons & 1880 & 276 \\
\hline Flakier I. & 1879 & 150 \\
\hline Halpern M, Krykun I & 1883 & 98 \\
\hline Hendler L. & 1880 & 65 \\
\hline Izenbek G. & 1900 & 60 \\
\hline Lewi I. & 1883 & 70 \\
\hline Markus I.A. & 1896 & 60 \\
\hline Nowik and sons & 1848 & 400 \\
\hline Polak and sons & 1877 & 65 \\
\hline Psachin M., Frejdking G. & 1904 & 57 \\
\hline Richter F. & 1870 & 136 \\
\hline $\begin{array}{l}\text { Bialystok Manufacturing Society } \\
\text { Becker E. and corp. }\end{array}$ & 1895 & 300 \\
\hline Trylling and son & 1863 & 220 \\
\hline
\end{tabular}

Source: [Werwicki, 1957]

After the II world war it took place last period of the development of the Białystok industry. Białystok became the important administrative, production and scientific centre. After 1945 the textile industry was destroyed in the considerable part. Its reconstruction caused in changeable political conditions. Apart from operating already prewar companies, in the period of the Polish People's Republic such industrial companies were started: industrial conglomerate Białystok Factory of the Cotton - Fasty, Factory of Carpets - Agnella, factory of electromechanical devices, factory of pre-fab houses - Fadom, etc. They were located according to local plans of developing, in zones of the industrial development, far away from the housing buildings. Although in Białystok also other industries developed, a textile one stayed dominating all the way to the beginning of the socioeconomic transformation, up to 1989. The architecture of industrial buildings carried out after 1945 differed much from of the prewar ones. Straight solids, plastered walls, halls built with the prefabricated technology, reinforced concrete didn't already have such expressive character, architectural climate and didn't become good material to renovation transformations - just for total conversion or demolition. 


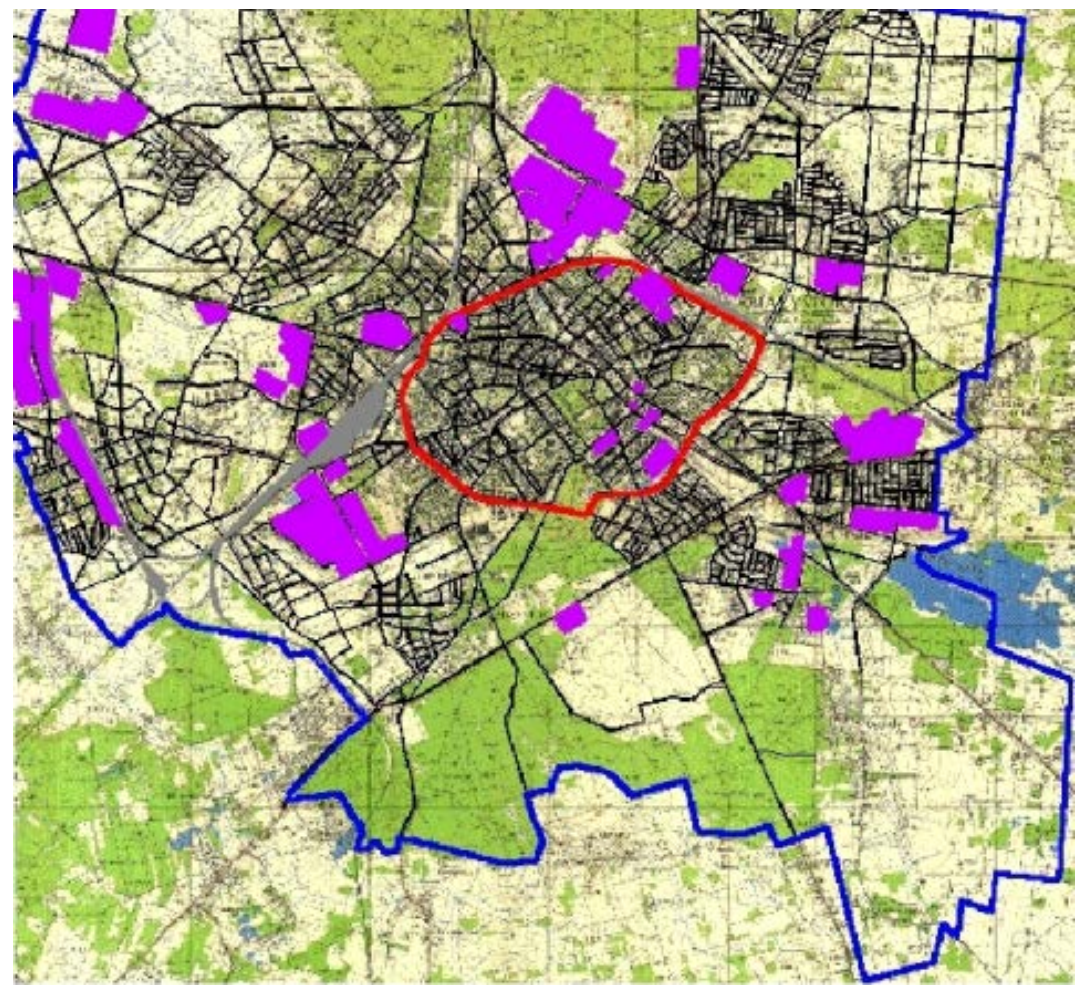

Fig. 2. Location of the biggest industrial factories in Białystok - state for 1985. Source: www. miastojutra.pb.bialystok.pl, accessed $17^{\text {th }}$ May 2017

\section{Revitalization of the postindustrial buildings into housing}

An interesting example of transformations of the industrial-stock space to housing is estate Tytoniówka in Białystok. Tytoniówka is an example of adoptation of the old tobacco Factory of Fajwel Janowski at Warsaw street 39. The factory was started in 1889, cigarettes were produced there, cigars and snuff. [www.sztetl.org.pl] Architectural office of the architect Janusz Kaczyński was the author of the reconstruction scheme. The plan was made in years 2006-2008, the realization took place in years $2008-2010$. In the project architecs tryied to achieve connecting between simplicity of factory rooms and the modernity. Luxury flats, lofts and some services are located in rebuilt buildings, ( two postindustrial buildings were left, modernized integrated into complex - Fig. 5 and Fig. 6). New buildings however are straight, designed almost in "minimal" style but with brick facades, with concrete and glass details.

Because of city centre character of the location and high cost of the area, the estate was designed in the intensive way (Fig. 3 and Fig. 4). The Urban concept is using - partly - existing traffic routes, both pedestrian as well as road. Moreover on edges, from Warsaw and Modlińska streets, as well as along the passage leading throw quarter from the Warsaw street, services were designed. Total amount of 155 flats have been designed in the quarter. [www.kaczynskiispolka.pl] The quarter has the shape of the extended interior on the axe northeats to south-west. Before tere was here a pedestrian way, linking the Bojary estate with the Warsaw street. At present this interior is closed, gated, available only to inhabitants. In this green interior, with the small square "between the factories", a recreational program was set up (Fig. 7). From it, through "gates" it is possible to get directly of private spaces of frontyards, accessible to only inhabitants and their guests. From that square some other functions - administrations, recreation e.g. fitness, fitness room, clinic of a family doctor, etc. are available. Under the entire housing complex of architects planned underground garage. From the level of parking it is possible to get with stairs and lifts to flats and services. Very carefully and consciously architects designed details. In order to keep character of the old factory they applied steel windows, other details of steel and cast irons. The simple details from architectural concrete, galvanized steel and wire glass make special charakter of zones where people stay (gates, balconies, small gardens, itp.). The composition of the facade from the side of 
the Warsaw street was organized using model of the industrial manufacturer palace. Only contemporary materials were used - glass, aluminium and steel-titanic metal sheet. In the gate a contemporary sculpture was situated - grogon basilisk defends the admission to the interior of the quarter (Fig. 8).

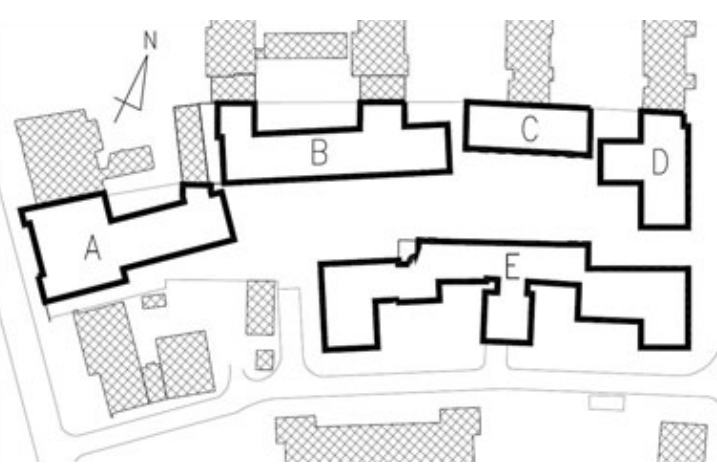

Fig. 3. Site plan of the Housing Estate Tytoniówka in Białystok (buildings $\mathrm{C}$ and $\mathrm{E}$ - were adopted). Source: www.kaczynskiispolka.pl, accessed $15^{\text {th }}$ September 2017

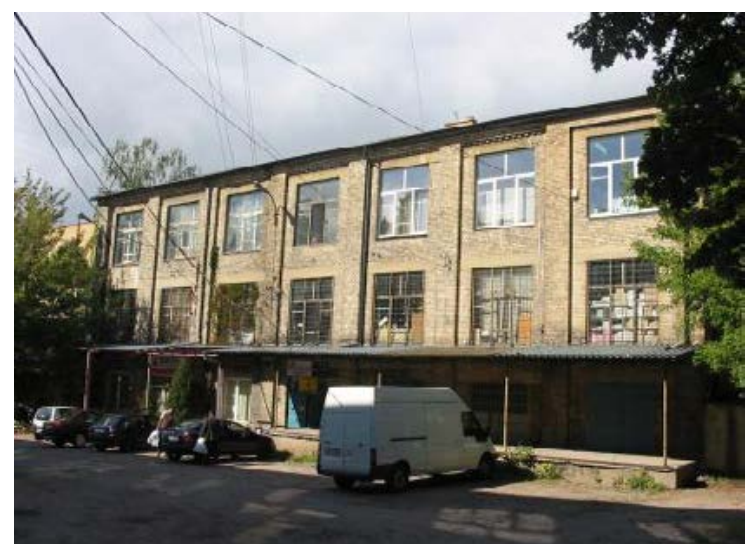

Fig. 5. (left) and Fig. 6. (right). One of postindustrial buildings before and after the modernization - estate Tytoniowka. Source: www.kaczynskiispolka.pl, accessed $20^{\text {th }}$ June 2017

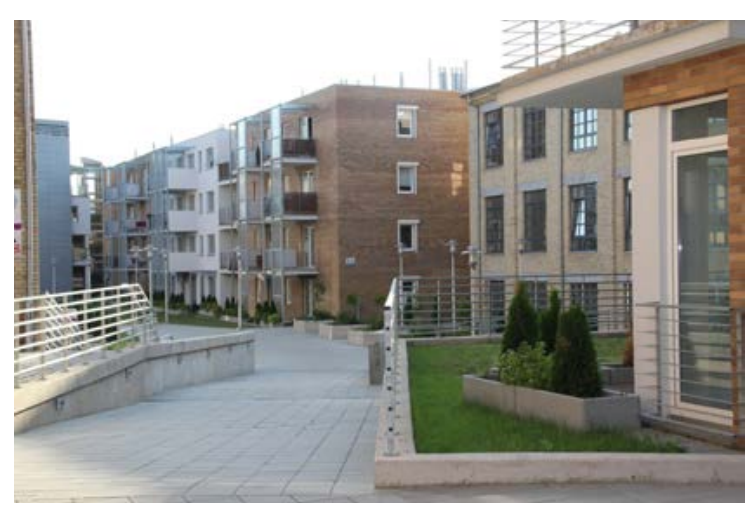

Fig. 7. Inside the quarter of the housing estate Tytoniowka in Białystok - pedestrian way. Source: photograph of the authors, 2017
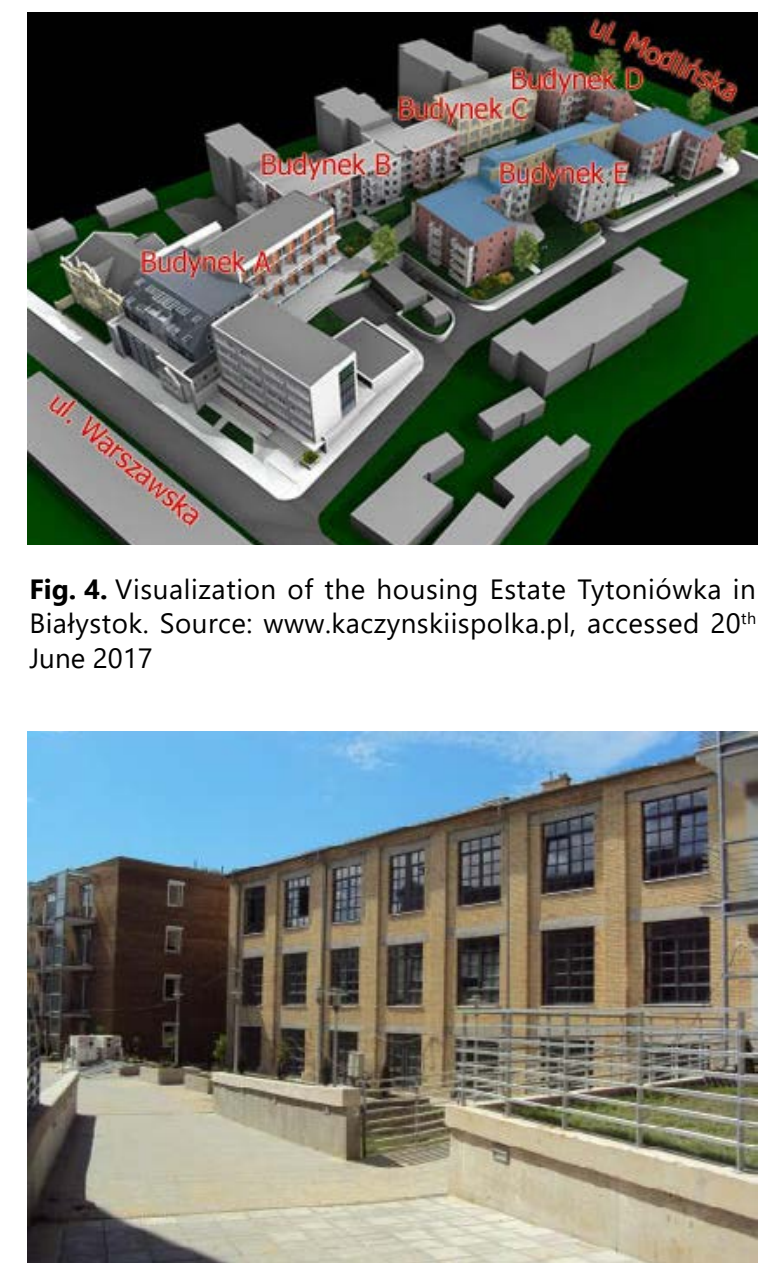

Fig. 4. Visualization of the housing Estate Tytoniówka in Białystok. Source: www.kaczynskiispolka.pl, accessed $20^{\text {th }}$ June 2017

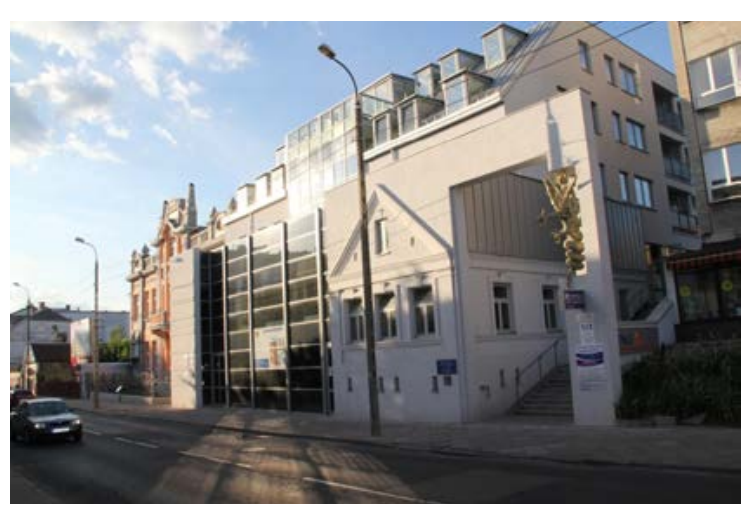

Fig. 8. Housing estate Tytoniówka in Białystok - front facade from the Warsaw street referring to the palace of the manufacturer. Source: photograph of the authors, 2017 


\section{Revitalization of the postindustrial development into commercial functions}

Commercial - service functions play significant role in transformations postindustrial areas. In the period of the changing Polish economy hypermarkets were the first building appiering in place of industry areas. Later, with the progress of planning - modern shopping centres with the public space inside started to be built. In Białystok we got good examples of such type of transformations in areas of two largest former factories E. Beckera's factory and C.Nowik's factory.

Eugeniusz Becker's factory of wool and silk was one of the biggest in Białystok in $19^{\text {th }} \mathrm{C}$. This German manufacturer settled down in Białystok in 1883. After 1895, [Lechowski, 2009] Eugeniusz Becker asked to the company the manufacturer August Moesem. The company started extending, the factory became tremendous complex, located along Mickiewicza and Swietojanska streets. There were magazines here, weaving milles, dyeworkses, wykańczalnie, stable (barn). In years 1902-1905 was built building of the management board, clearly referring to the French Renaissance (so-called Becker's palace). [Dolistowska, 1996] after the II world war the factory was nationalized and called Biruna. The production lasted till 2007, when the Biruna enterprise was moved out of Białystok to Wasilkow and private owner decided to sale the hole area. Into this way Alfa centre came into existence.

In March of 2007 a process of the revitalization of old buildings and factory started. Investor - company JWK-Inwest-Management from Gdynia - asked to design revitalization koncept of the complex of the studio of architect Maciej Kuryłowicz. According to recommendations of the monument conservation office, a wall of red bricks was kept from the side of the street, also former building of Mercury and stables (barn) from $1911 \mathrm{r}$. Historic buildings were integrated into new complex. Shops and offices were located in the centre, and in the old stable was trnsformed into a café.

Architects had to compose and join modern part of the object with historical parts. Inside the building brick walls are next to modern materials, roofs fitted with glass and the escalator, linking floors. New lifts with appearance are referring to old factory lifts. The centre has the 86 thousand $\mathrm{m}^{2}$ of the area, the 35 thousand $\mathrm{m}^{2}$ is filling 150 shops placed on three storeys. Apart from them, in the centre a cinema is functioning with seven rooms, some restaurants, the climbing wall and the fountain on the first storey. In basements the underground garage for almost 800 cars was designed. It seems, that concept of the revitalization connecting elements of architecture from the $19^{\text {th }}$ century and modern solution was perfect. A cohesion was kept with original industrial character of the place. Gallery the Alpha was opened in October 2008 as the commercial - recreational centre. [www.skyscrapercity.com] The cost of construction was over 100 million USD.

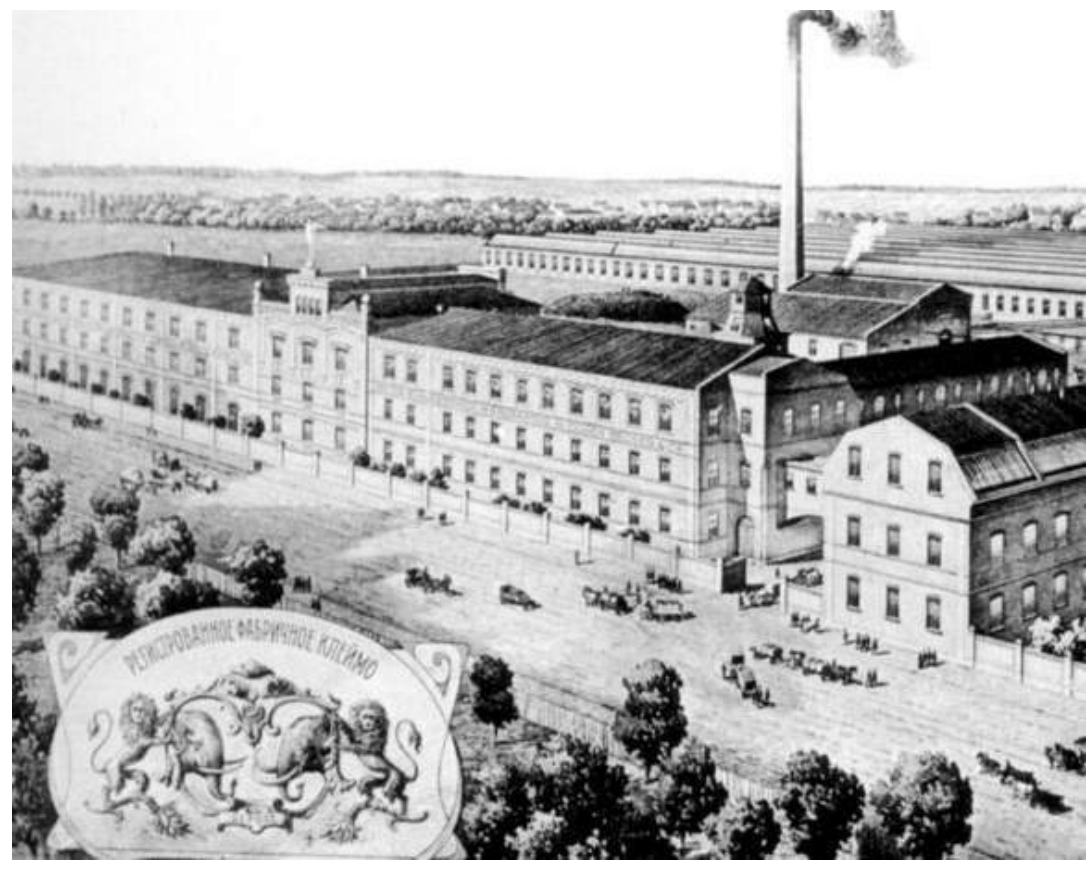

Fig. 9. E. Becker's factory in Białystok along Swietojanska street - the first decade of the $20^{\text {th }}$ century source: www.poranny. $\mathrm{pl}$, accessed $25^{\text {th }}$ June 2016 

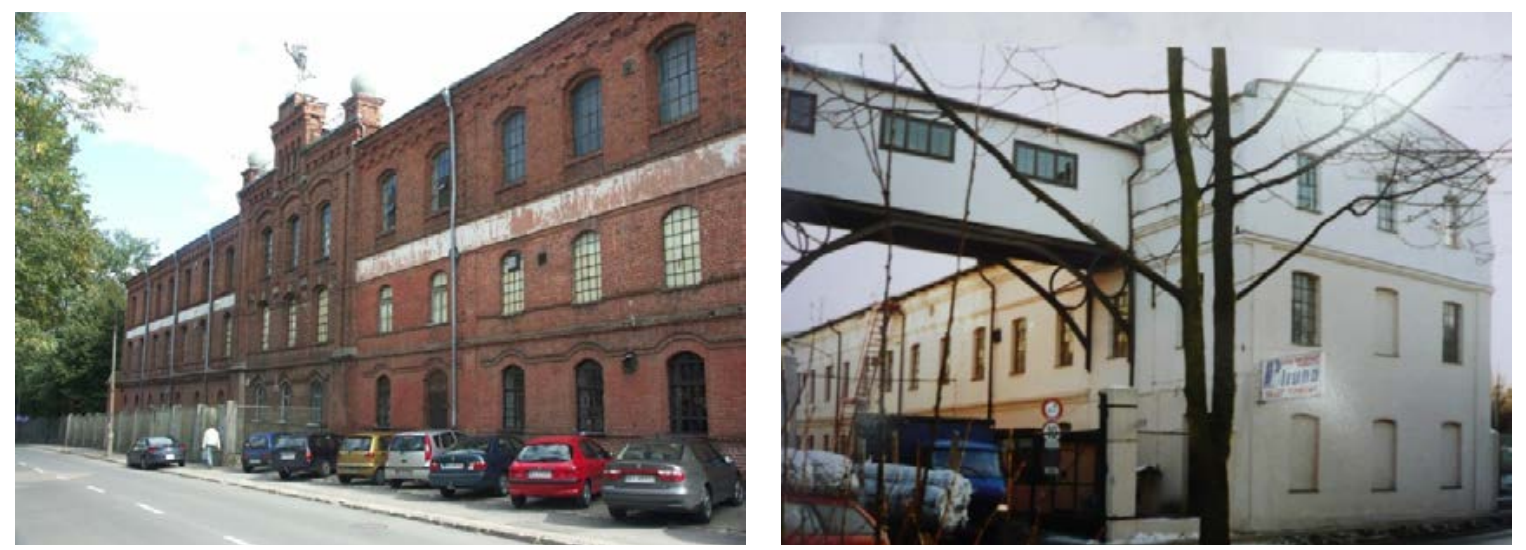

Fig. 10. and Fig. 11. E. Becker's factory in Białystok - views, 1999. Source: photograph of the authors, 1999
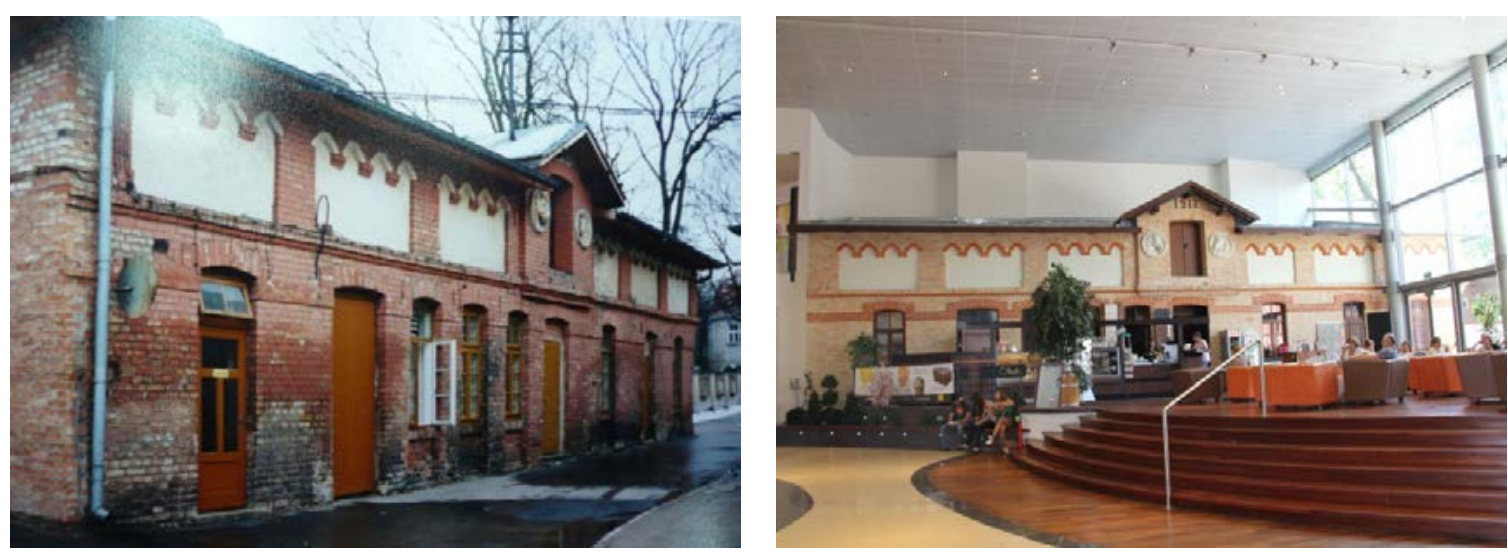

Fig. 12. and Fig. 13. Stable in the Becker's factory - state from 1999 and after the revitalization inside the complex of the gallery (2010). Source: photographs of the authors, 1999 and 2010

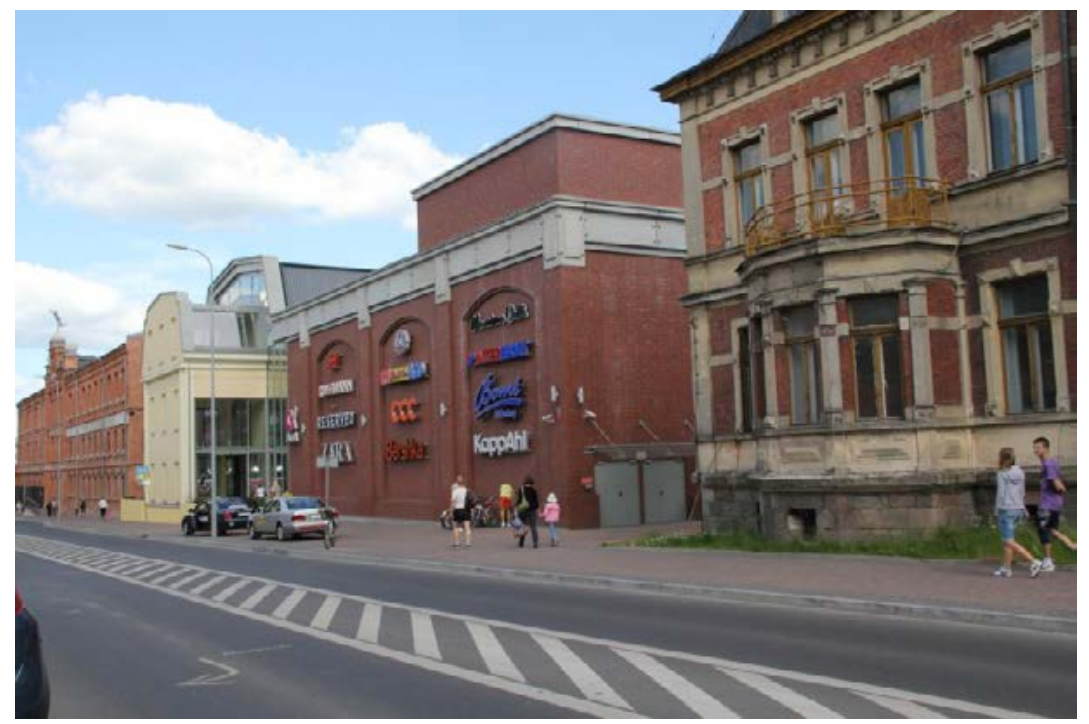

Fig. 14. Complex of Alfa Centre (former Becker's Factory) - after the revitalization from the side of Swietojanska street. Visible new and old, restored buildings, state in 2011. Source: photograph of the authors, 2011

Another interesting example of revitalization was C. Nowik's Factory - large Białystok textile company, located within streets of Mickiewicza and Augustowska. Complex of textile factories "Nowik and sons" dates back with its roots of years 90 . of the $19^{\text {th }}$ century. The factory was made in a few stages, Factory of the Cloth and 
Hats "Nowik and sons" was a full-production unit, one from biggest in Białystok - before the II world war 400 workers worked there (Fig. 15). [Dobronski, 1998]. The Second World War caused great damage to factory. In 1944 German army destroyed the factory buildings. After 1945 was rebuilt and existed to years of 90 . the $20^{\text {th }}$ century (Fig. 16 and Fig. 17). In 2006 the city decided to sell the land and private inwestor started to build - on area of the old Nowik's factory - first in Białystok commercial and entertainment centre - Biala Atrium. From old buidings factory only a water tower and two administration buildings were left near Augustowska street (Fig. 20). The investor didn't keep any old walls or details. [Lechowski, 2009] Biala centre - is the first commercial and entertainment centre built in this city. The inauguration of activity was held in December 2007 (Fig. 18). It isn't possible to deny investors did not want to sefe spilit of the place. Therefore on the elevation from the Miłosz street architects built walls with details resembling the roof of old industry building. From the side of undergruond garage (Branicki street) they designed a few concrete vaults standing in front, also reminding the form of old building Nowik's Factory (Fig. 19). However the palette of ideas of designers is limited to these examples - details seems to be artificial, not natural.

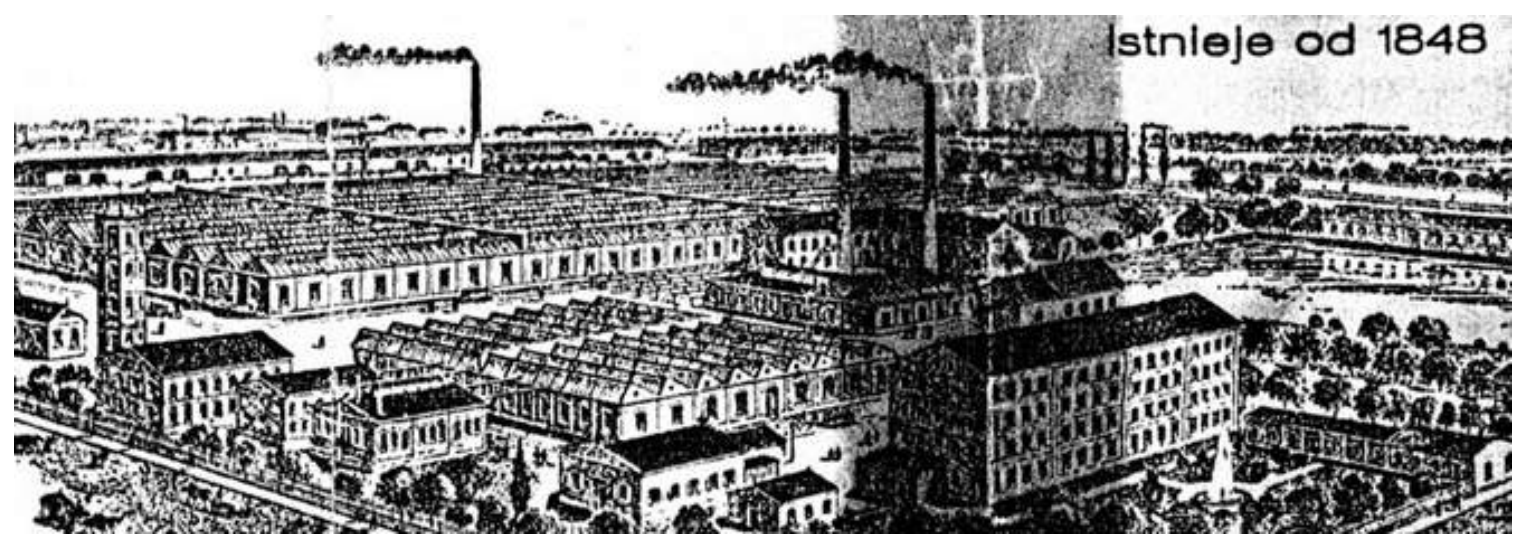

Fig. 15. C. Nowik's factory in Białystok - view, state at first decade of the $20^{\text {th }}$ century. Source: www.poranny.pl, accessed $25^{\text {th }}$ June 2016
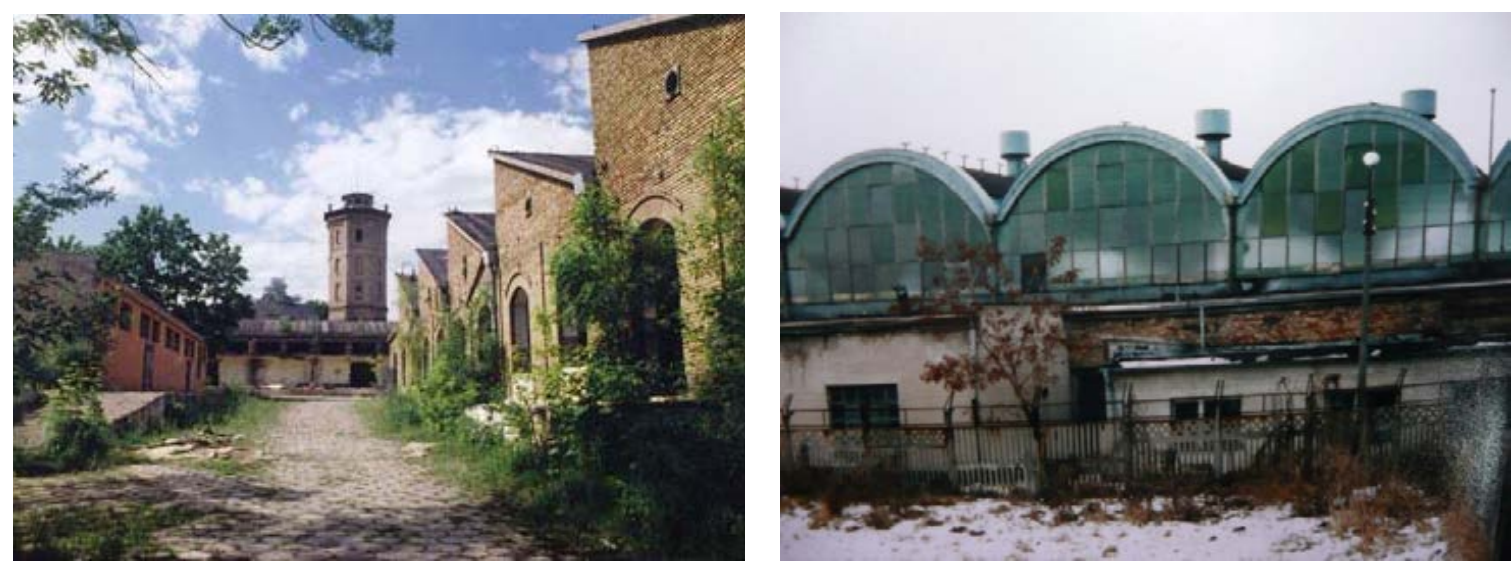

Fig. 16. and Fig. 17. Nowik's factory in Białystok - state from the end of $20^{\text {th }}$ century. Source: photographs of the authors, 2000 


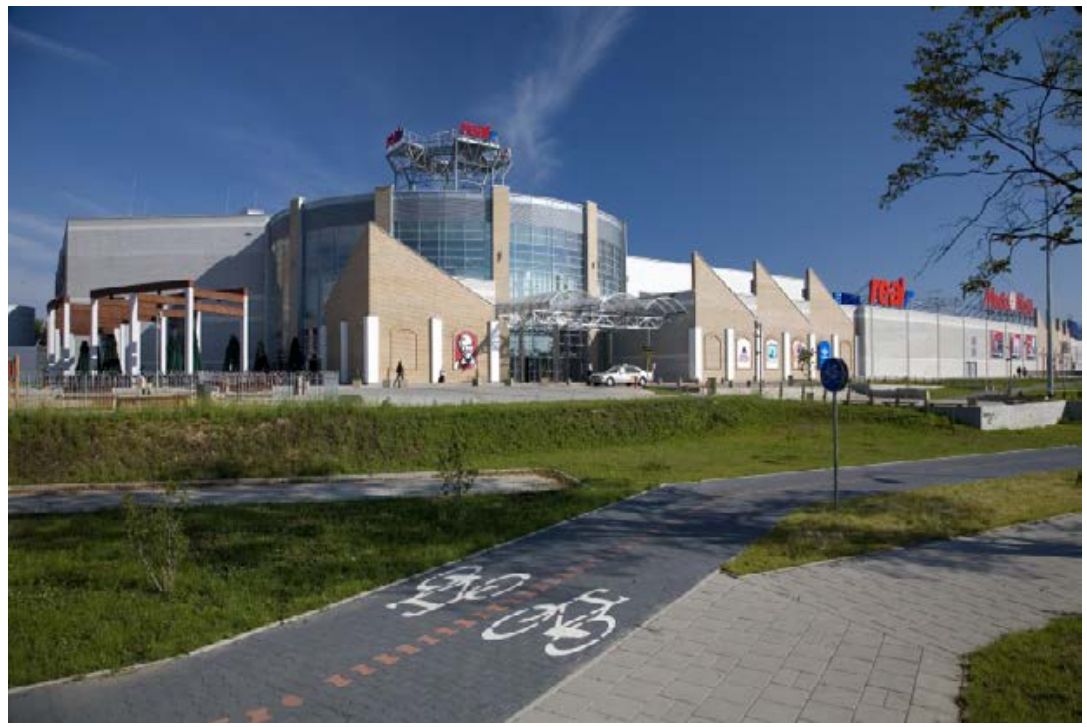

Fig. 18. Biala centre - new building in the place of the old factory - view from the side of the main entrance. Source: photograph of the authors, 2016

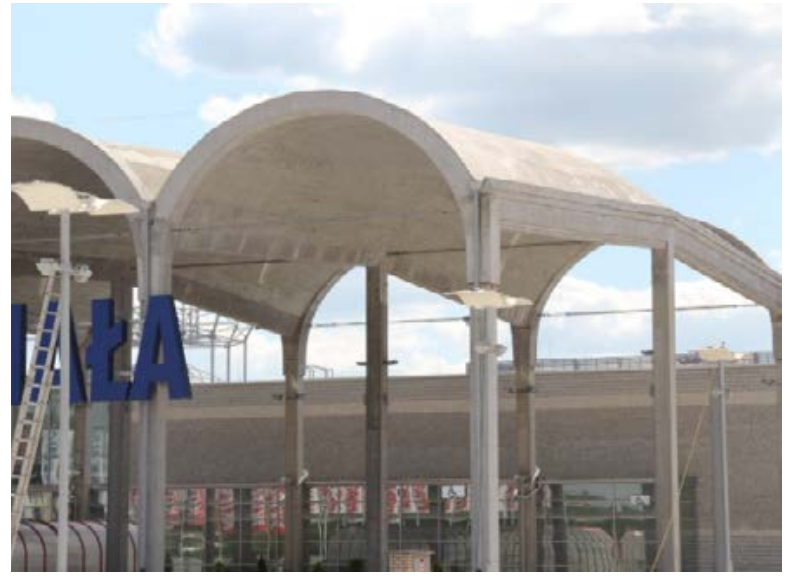

Fig. 19. Reinforced concrete vaults on the car park of the Biala Centre. Source: photograph of the authors, 2011

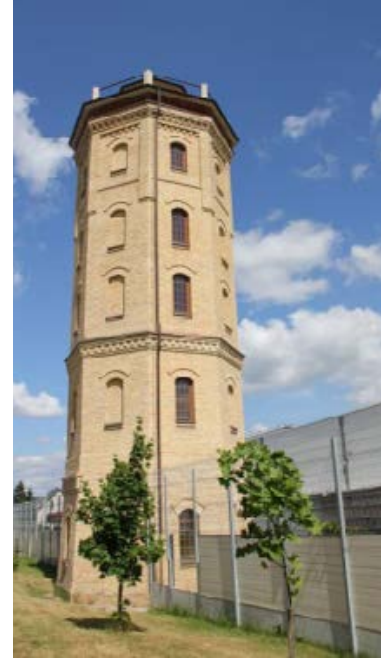

Fig. 20. One of three old buildings left from Nowik's factory - water tower, at Augustowska street. Source: photograph of the authors, 2011

\section{Other postindustrial buildings - unknown future}

In spite of very good, impressive examples of revitalization actions made in the beginning of $21^{\text {st }}$ century in Bialystok - there are more than 10 other postindustrial factories and buildings waiting for changes. Some of them have good locations in the city centre, some are in the better technical condition, some are getting ruined year by year. It seems that there must be establied very strong political will from the city management to start further revitalizations and strong will for the cooperation with potential investors. This is difficult but looking for the great achievements so far - it seems to be possible. This is the next step and also the chance for development the city of Bialystok in $21^{\text {st }}$ century. 


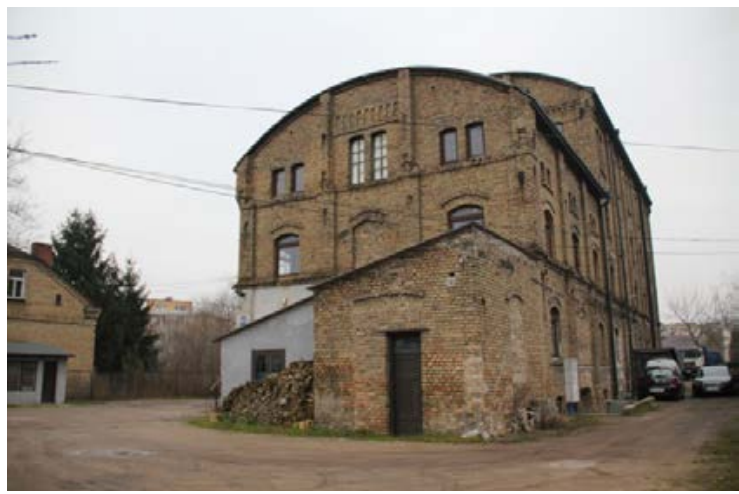

Fig. 21. Old postindustrial building at Poleska street, Bialystok - waiting for changes (left). Source: photograph of the authors, 2018

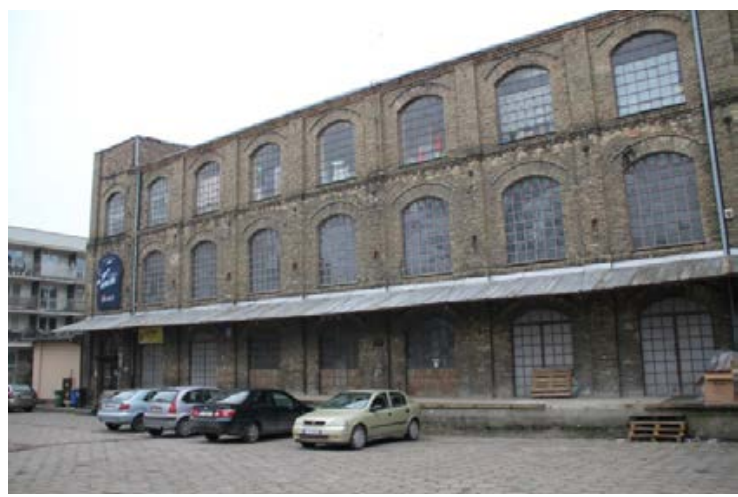

Fig. 22. Postindustrial factory at Czestochowska street, Bialystok - waiting for changes (right). Source: photograph of the authors, 2011

\section{Conclusion}

Transformations of postindustrial areas became very important elements of the development of some Polish cities at the beginning of the $21^{\text {st }}$ century. Old factories are often characterized by great dimensions, they usually occupied entire quarters or large spaces in cities. Because of characteristic urban and architectural elements (e.g. towers, chimneys, details, applied materials - usually brick, special "climate" of the building development, etc.) - they play important role in the city landscape. Such buildings are creating the spirit of places, identity of our cities, including Białystok. Mentioned above examples are demonstrating, how important processes of the revitalization of postindustrial development took place in the last decade in Bialystok. Transformations of that analysed buildings led to the change of both the spatial and functional structures of complexes. In addition in case of transformations of the Becker's Factory and "Tytoniówka" Factory - an identity of Białystok has not gone; architects and urban designers managed to keep some elements of industrial architecture (at least in some parts) [Tokajuk, 2007]. We can here talk about real revitalization - we got a new spatial and functional order. In case of the Biala Atrium Centre on the place of former Nowik's Factory- it isn't a positive example of revitalization. Demolishing the old factory and developing on its place the new, large-spatial building structure, with details imitating the shape of industrial roofs or vaults, is not a good metod, it is a mistake. This simple way of action was chosen, but we lost the former identity to next generations. It is hard to call it the real revitalization of the city quarter, because it is a new construction. The very important aspect of revitalization postindustrial buildings in Bialystok is the economical one. We must remember, that in these old factories many people worked some time ago. Because of the economical changes the companies collapsed, buisnesses stopped and people lost their jobs. Now a lot of money was invested to make modernization and revitalization processes ( for instance more than $100 \mathrm{mln}$ US dollars in case of Alfa centre). And thanks to that many hundreds new job places were started (it is estimated that in two new shopping malls: Alfa and Biala more than 1000 people found their new jobs). That is significant number which has big positive influence for labour market in the city of Bialystok. Remodelling of postindustrial areas, particularly in city centres is the occasion to the new spatial order. It seems, that such chance in Białystok - they managed to do very well so far. Positive examples aroused also a greater awareness and approval to this type of action in the future.

\section{References}

[1] Dobroński A., Białystok historia miasta, Zarząd miasta Białegostoku, Białystok 1998.

[2] Dolistowska M., Rozwój zabudowy ulicy Świętojańskiej w 2. połowie XIX wieku i w 1. połowie wieku XX, [w]: Ochrona reliktów urbanistycznych Białegostoku, Wyd. Politechniki Białostockiej, Zeszyty Naukowe PB, Białystok $1996, \mathrm{nr} 16$. 
[3] Gorgoń, Sikorska-Starzewska J. A., Uspołecznienie procesu tworzenia miejskiego programu rewitalizacji na przykładzie Częstochowy, [w]: Instrumenty zarządzania rewitalizacją zdegradowanych terenów poprzemysłowych oraz obszarów odnowy miejskiej, Praca pod red. Sikorska-Starzewska A., Wydawnictwo Ekonomia i Środowisko, Białystok 2007.

[4] Jadach-Sepioło A., Rewitalizacja miast w dokumentach strategicznych w Polsce. Odniesienie do projektu Krajowej Strategii Rozwoju Regionalnego 2010-2020: regiony, miasta, obszary wiejskie, [w]: O budowie metod rewitalizacji w Polsce - aspekty wybrane, pod red. Skalski K., Instytut Rozwoju Uniwersytetu Jagiellońskiego w Krakowie, Kraków 2010.

[5] Korzec P., Pół wieku ruchu rewolucyjnego Białostocczyzny (1864-1914), Warszawa 1965.

[6] Lechowski A., Białystok. Przewodnik historyczny, Wyd. Dom Wydawniczy Benkowski, Białystok 2009.

[7] Lorens P., Specyfika procesów przekształceń i rewitalizacji różnych obszarów zdegradowanych w miastach polskich, [w]: Wybrane zagadnienia rewitalizacji miast, pod. red. Lorens P., Martyniuk-Pęczek J., Wydawnictwo Urbanista, Gdańsk 2009.

[8] Markowski T., Zarządzanie rozwojem miast, PWN, Warszawa 1999.

[9] Podręcznik rewitalizacji. Zasady, procedury i metody działania współczesnych procesów rewitalizacji, Urząd Mieszkalnictwa i Rozwoju Miast, Warszawa 2003.

[10] Sumień T., Furman-Michałowska J., Ufnalewska K., Wąs W., Odnowa miast europejskich, Instytut Gospodarki Przestrzennej i Komunalnej, Warszawa 1989.

[11] Tokajuk A., Próba identyfikacji elementów tożsamości miasta na przykładzie Białegostoku, Zeszyty Naukowe Politechniki Poznańskiej. Architektura i Urbanistyka, Wyd. PP, Poznań 2007, nr 12.

[12] Wasiluk H., Oddziaływanie przemysłu włókienniczego na architektoniczny obraz Białegostoku w XIX i XX wieku, praca doktorska, Wydział Architektury Politechniki Warszawskiej, Białystok 1998.

[13] Werwicki A., Białostocki okręg przemysłu włókienniczego do 1945 roku, PWN, Warszawa 1957.

[14] http://www.miastojutra.pb.bialystok.pl, accessed 17 th May 2017.

[15] http://www.sztetl.org.pl, accessed 10 $10^{\text {th }}$ April 2011.

[16] http://www.kaczynskiispolka.pl, accessed 15 th September 2017.

[17] http://www.poranny.pl, accessed 25th June 2016.

[18] http://www.skyscrapercity.com, accessed 25 th June 2016. 